\title{
JAMES WHITE
}

University of Alberta

\section{Excising the Foreign: Islamophobia and the 2012 Circumcision Ban in Cologne, Germany}

The practice of circumcising male children for religious purposes is a fraught issue that brings into confrontation questions of religious freedom, bodily integrity, the rights of parents to make decisions for their children, and-in Europe and North America, at least-minority rights. Although male circumcision is by no means limited to practitioners of Judaism and Islam, Jews and Muslims are, by far, the groups in the West who most frequently circumcise their male children for religious reasons. Yet even amongst those groups, not everyone is in favor of circumcision. Reconstructionist Rabbi Elyse Wechterman, for example, not only opposes circumcision, but has devised a swaddling ceremony that she offers in lieu of ritual circumcision for those Jewish parents who are unwilling to circumcise their sons. ${ }^{1}$

The majority of circumcisions in the United States and Canada are performed for medical or aesthetic reasons, rather than religious ones. As scholar and anti-circumcision advocate Leonard Glick notes, “[American] Jews almost never question how circumcision can define their ethnic individuality in a country where tens of millions of Gentile males have genitals indistinguishable from the Jewish version — and where an unknown but possibly substantial number of Jewish boys and men have not been circumcised" [emphasis original]. ${ }^{2}$ In Europe, by contrast, male circumcision is almost exclusively confined to observant Jews and Muslims.

\footnotetext{
${ }^{1}$ Elyse Wechterman, “A Plea for Inclusion,” in The Covenant of Circumcision, ed. Elizabeth Wyner Mark (Hanover and London: Brandeis University Press, 2003), 188-193.

${ }^{2}$ Leonard B. Glick, Marked in Your Flesh: Circumcision from Ancient Judea to Modern America (New York: Oxford University Press, 2005), 8. Glick, a circumcised Jew, is vehemently opposed to male circumcision. See Michael Benatar and David Benatar, "Between Prophylaxis and Child Abuse: The Ethics of Neonatal Male Circumcision,” The American Journal of Bioethics 3.2 (2003): 35-48; the response by Rio Cruz, Leonard B. Glick, and John W. Travis, "Circumcision as Human-Rights Violation: Assessing Benatar and Benatar," The American Journal of Bioethics 3.2 (2003): 19-20; and Benatar and Benatar's tart rejoinder "3:2 Target Article Authors respond to Commentators: How Not to Argue about Circumcision,” The American Journal of Bioethics 3.2 (2003): 1-9.
} 
The constellation of religious freedom, inviolability of the body, parental rights, and secularism is exemplified by a 2012 ruling by the regional court (Landgericht) in Cologne, Germany, which banned the circumcision of male children for religious reasons. In its ruling against the Muslim physician who had performed the circumcision in question, the court cited such concerns as bodily integrity (körperliche Unversehrtheit) and a narrow definition of the rights of parents to provide their children with a religious upbringing (religiöse Kindererziehung). ${ }^{3}$ Although the Bundestag later proclaimed a resolution that male circumcision was an integral component of religious freedom in Germany, it seems probable that the original case and its ruling in Cologne were as motivated by Islamophobia and the increasing presence of a Muslim religious practice in Germany as by ostensibly secular arguments. I propose that the weight given to the issues of bodily integrity and parental rights - in themselves, valid and worthwhile concerns - acted as a smokescreen to disguise the unease experienced by the majority, Christian German population when faced with a "foreign" religious practice. To advance this thesis, I will draw upon scholarship that explores the complicated nature of German laws regarding ritual slaughter as practised by Muslims, another minority religious practice that has faced circumscription based on putatively secular concerns.

Before delving into an analysis of the 2012 circumcision ban in Cologne, Germany, it is important to provide some context. Circumcision rates of newborn males vary widely from country to country with a worldwide average of 10-20 percent. Rates are highest in Israel and in countries with a predominantly Muslim population. Worldwide, the incidence of circumcision for Jewish newborns is greater than 95 percent, and among Muslims, the rate rises to 95 percent by adulthood. In the United States, 65 percent of all newborn males are circumcised, while in Canada, approximately one in three male infants undergoes circumcision. ${ }^{4}$ These two countries contain the highest number of men circumcised for non-religious

\footnotetext{
${ }^{3}$ Landgericht Köln, Urteil 151 NS 169/11, IWW Institut, accessed March 30, 2015, http://www.iww.de/quellenmaterial/id/85915.

${ }^{4}$ Mark C. Alanis and Richard S. Lucidi, "Neonatal Circumcision: A Review of the World's Oldest and Most Controversial Operation," Obstetrical and Gynecological Survey 59.5 (2004): 383. Alanis and Lucidi note that rates were similarly high in England before the introduction of national socialized medicine, when circumcision was labeled as an elective surgery.
} 
purposes, due to advocacy for circumcision in late nineteenth- and early twentiethcentury English-language medical literature, which argued that the operation could cure physical ailments, such as headaches and stress, as well as what were perceived as moral sicknesses, including masturbation. ${ }^{5}$ More recently, in the United States, the American Academy of Pediatrics has been inconsistent in its stance on male circumcision, stating in 1999 that data for the benefits of circumcision were not sufficient to recommend it as a routine procedure. ${ }^{6}$ In its most recent statement, however, the Academy determined in 2012 that the benefits of circumcision include decreased urinary tract infections, the prevention of penile cancer, and a reduction in the transmission of sexually transmitted diseases, including HIV. The Academy concluded that "although health benefits are not great enough to recommend routine circumcision for all male newborns, the benefits of circumcision are sufficient to justify access to this procedure for families choosing it and to warrant third-party payment for circumcision of male newborns."7

In Germany, however, as in most of Europe, circumcision rates are much lower. Data from 1985 suggest that less than 1 percent of male newborns in Germany were circumcised. ${ }^{8}$ Rates are similar in Scandinavia and Russia. England has a slightly higher incidence of 6 percent, probably due to lingering effects of the Victorian- and Edwardian-era circumcision advocacy discussed above. ${ }^{9}$ In Germany, Muslims constitute approximately 3.7 percent of the population while Jews make up less than 0.5 percent. ${ }^{10}$ Because Muslims do not always practise infant circumcision, as will be discussed shortly, the incidence of circumcision, combined with the percentage of the German population who identify as Jewish or Muslim, indicates a reasonable conclusion that the circumcision of male newborns in Germany is almost entirely limited to practitioners of Judaism and Islam. These figures also indicate that the majority of circumcised men in Germany are Muslim.

\footnotetext{
${ }^{5}$ Glick, Marked in Tour Flesh, 149-214, provides an extended discussion of this literature, including the role of Jewish American physicians in twentieth-century circumcision advocacy.

${ }^{6}$ Alanis and Lucidi, "Neonatal Circumcision," 382.

7 American Academy of Pediatrics, "Circumcision Policy Statement," Pediatrics 130.3 (2012): 585.

8 Steven E. Lerman and Joseph C. Liao, "Neonatal Circumcision," Pediatric Clinics of North America 48.6 (2001): 1541.

9 Alanis and Lucidi, "Neonatal Circumcision," 383.

${ }^{10}$ Gerhard Robbers, "The Legal Status of Islam in Germany," in Islam and European Legal Systems, eds. Silvio Ferrari and Anthony Bradney (Burlington, VT: Ashgate, 2000), 147.
} 
Both Jews and Muslims trace the religious injunction to practise male circumcision to authoritative texts - the former to the book of Genesis in Hebrew scripture and the latter to an authentic hadith from the established tradition or Sunnah of Muhammad. In Chapter 17, God establishes his covenant with Abram, not only changing the latter's name to Abraham, but also instructing him: "Every male among you shall be circumcised. You shall circumcise the flesh of your foreskin, and it shall be a sign of the covenant between me and you. Throughout your generations every male among you shall be circumcised when he is eight days old" (Genesis 17.10-12). God proceeds to clarify that although his covenant will extend to Abraham's as-yet-unborn child Isaac, he will also bless Ishmael, the son Abram fathered with the slave Hagar. Genesis then narrates the circumcision of Abraham, all the men in his house, and Ishmael. Jews continue to ritually circumcise male infants when they are eight days old. Muslims, who trace their Abrahamic lineage through Ishmael, stipulate that male children must be circumcised by the time that they are thirteen years old, the age of Ishmael at the time of his circumcision (Genesis 17.25). Thus, while Jews specify an exact day on which circumcision must occur, Muslims instead indicate only a maximum age by which the ritual must take place. ${ }^{11}$ Male circumcision is mentioned sporadically elsewhere in Hebrew scripture (e.g., Exodus 4.24-26, Leviticus 12.3, and Joshua 5.3-7), and both the Talmud (for Jews) and hadith (for Muslims) contain additional prescriptions for the practice. ${ }^{12}$

Having established the context surrounding the 2012 ban on circumcision in Cologne, Germany, it is time to turn toward that prohibition itself. On November 4, 2010, a Muslim physician in Cologne performed a circumcision on a four-year-old Muslim boy under local anaesthesia. The court's judgment notes that the procedure

\footnotetext{
${ }^{11}$ Glick, Marked in Your Flesh, 20-22, argues, based on Leviticus 12.2, that male infants could not be younger than eight days old when they were circumcised because for the first week of their lives, an infant remained with its mother and was considered to be ritually impure by reason of contact with her parturitional blood.

12 As a representative example, Nissan Rubin, “Brit Milah: A Study of Change in Custom,” in The Covenant of Circumcision, ed. Elizabeth Wyner Mark (Hanover and London: Brandeis University Press, 2003), 87-88, argues that rabbis instituted the practice of periah, by which all skin around the penile glans was removed during circumcision, after the Bar Kokhba Revolt to prevent Jewish men from passing as Gentiles by slowly drawing the leftover foreskin flesh over the glans.
} 
was performed at the request of the parents and without "a medical indication." 13 The physician gave the child four stitches and visited him at home that evening. On November 6, 2010, the child's mother took him to the University Children's Hospital in Cologne to treat post-operative bleeding, which was staunched at the hospital. A state prosecutor brought charges against the physician in 2011; the case was acquitted by the Cologne district court (Amtsgericht) on September 21, 201 1. ${ }^{14}$ Krüper notes that in its judgment, the district court argued that the circumcision would preclude stigmatization in the boy's religio-cultural environment and that it could have hygienic motivations. ${ }^{15}$ Unsatisfied, the state prosecutor renewed his case in 2012 in the regional court, which ruled that the physician would not face any legal charges because he was fully acting under the belief that "as a pious Muslim and qualified doctor" (als frommem Muslim und fachkundigem Arzt) he was allowed to perform circumcision for religious reasons. Nevertheless, although the ruling only officially applied to the Cologne region, it did state, in more general terms, that the desire of the parents to education their children and to bring them up in the Islamic faith did not overrule the child's right to bodily integrity. The court additionally noted that children could decide for themselves, when they were older, whether they wished to have "a visible sign of belonging to Islam” (ein sichtbares Zeichen der Zugehörigkeit zum Islam). ${ }^{16}$

Although, as noted, the court did not expressly prohibit circumcision and its ruling only applied to the jurisdiction of the Cologne court, the decision was taken in the German and international press as prohibiting circumcision throughout Germany. Der Spiegel understood the ban to have implications for all of Germany and reported the criticism leveled against the ruling by the Central Council of Jews in Germany; at the time of press, the Central Council of Muslims had not provided a statement. ${ }^{17}$ The BBC reported that after the ruling, the Jewish Hospital in Berlin,

\footnotetext{
${ }^{13}$ Landgericht Köln.

${ }^{14}$ Landgericht Köln.

15 Julian Krüper, "Entscheidungsanmerkung: Religionstradition und Rechtskonvention: Die

Unzulässigkeit religiöser Knabebeschneidung,” Zeitschift für das Juristische Studium 4 (2012): 548.

${ }^{16}$ Landgericht Köln.

${ }^{17}$ Barbara Hans, “Landgericht Köln: Beschneidung aus religiösen Gründe ist strafbar,” Spiegel Online, accessed March 23, 2015, http://www.spiegel.de/panorama/justiz/religioes-motiviertebeschneidung-von-jungen-ist-laut-gericht-strafbar-a-841084.html.
} 
which had performed circumcisions for 250 years, halted its planned circumcision operations of both Jewish and Muslim boys. Mohammed Asif Sadiq, a Muslim leader in Berlin, told the BBC that he feared that circumcisions would continue, but in less hygienic conditions. Alternatively, he warned, devout Jews and Muslims would have circumcisions performed outside of Germany, perhaps in their homelands, in the case of Muslim immigrants. ${ }^{18}$

It does seem, however, that the media's nationwide interpretation of the ruling was not without justification. Two months after the ruling by the Cologne court, the New York Daily News reported that Rabbi David Goldberg, in the Bavarian city of Hof, faced legal charges for circumcising a male infant after an unidentified physician filed a criminal complaint, citing bodily injury to the child. ${ }^{19}$ The resolution passed by the Bundestag in late 2012 to keep religious circumcision legal in Germany cleared Rabbi Goldberg of his charges. Writing after that resolution was passed, Deutsche Welle emphasized the national debate that had occurred after the Cologne ruling, noting that "the decision [in Cologne] prompted many Jews and Muslims to question their acceptance and sense of feeling spiritually at home in Germany.” 20

Although the debate was ultimately solved at the federal level, Cologne's ban on religious circumcision holds important questions about the place of religion in western, secular societies. Moreover, it brings to light the ways in which concerns understood to be secular by the Cologne court-for example, the health of children and what it means to feel secure in one's home or adopted country — can be wielded to challenge religious practices. In order to understand the 2012 circumcision ban in Germany, it is helpful to make use of scholarship on another religious practice in Germany, that of ritual slaughter.

\footnotetext{
18 Stephen Evans, “German circumcision ban: Is it a parent's right to choose?”, $B B C$, accessed March 22, 2015, http://www.bbc.com/news/magazine-18793842.

19 Christine Roberts, "The unkindest cut of all: German rabbi faces charges for performing newly outlawed circumcision procedure,” New York Daily News, accessed March 24, 2015, http://www.nydailynews.com/life-style/health/unkindest-cut-german-rabbi-faces-chargesperforming-newly-outlawed-circumcision-procedure-article-1.1142324.

${ }^{20}$ Kay-Alexander Scholz, "Circumcision remains legal in Germany," Deutsche Welle, accessed March 23, 2015, http://dw.de/p/16oDQ.
} 
Before doing so, however, it is useful to pause briefly and consider the concepts of religion and secularism. For the purposes of this article, I follow Talal Asad when he asserts that the secular "is neither continuous with the religious... nor a simple break from it." ${ }^{11}$ In the case of Germany, a majority Christian nation, Gil Anidjar's statement that Christianity has "reincarnated itself as secular [emphasis original]" is important. ${ }^{22}$ Issues raised in this study-bodily inviolability, parental rights - certainly have religious, as well as non-religious, meanings. Those nonreligious meanings, labelled in this article as "secular" to reflect the approach taken by the Cologne court, are actually, often Christianoform in nature. We will see that the court understood circumcision through a secular/Christian lens and used its powers to challenge non-secular/non-Christian practices. This approach, however, was not limited to the 2012 circumcision ban; rather, it also appears in Germany's understanding of ritual slaughter.

Ritual slaughter is practised by both Jews (kosher shechita) and Muslims (halal slaughtering). Both religious groups hold that an animal must be killed with compassion; the general practice is to sever, with one quick motion, the animal's trachea, esophagus, and the veins and nerves in the neck. Animals are allowed to bleed out via the cut in the neck. ${ }^{23}$ Both observant Jews and Muslims prohibit the consumption of animals that have suffered injury or that have been killed by other means. This includes the common western practice of stunning animals (either by blunt force or electric shock) before slaughter, a procedure that is often argued to be more humane than ritual, stunless slaughter. ${ }^{24}$ Indeed, the Qur'an expressly forbids the consumption of animals "killed by strangling or by a violent blow" (Surah 5.3).

Recently, in 1995, a federal German court banned Muslims from practising the ritual slaughter of animals, arguing that the practice was not required in Islam

${ }^{21}$ Talal Asad, Formations of the Secular: Christianity, Islam, Modernity (Stanford: Stanford University Press, 2003), 25.

22 Gil Anidjar, “Secularism,” Critical Inquiry 33.1 (2006): 60.

23 The Jewish scriptural injunctions can be found at Deut. 12.21 and 14.21. The Muslim prescription can be found at Quran, Surah 5.3.

${ }^{24}$ Shechita and halal slaughter are, of course, not identical. A Muslim slaughterer, for example, does not have to be a trained expert, and there are some fatawa that permit stunning as long as the animal remains alive before its throat is cut. In their essentials, however, the ritual slaughter practices of Jews and Muslims are similar. See Pableo Lerner and Alfredo Mordechai Rabello, "The Prohibition of Ritual Slaughter (Kosher Shechita and Halal) and Freedom of Religion of Minorities," Journal of Law and Religion 22.1 (2006/2007): 11. 
and was thus not protected by the German constitution's guarantee of religious freedom. The court gave as an additional reason the fact that Germany's Muslims were not unified and instead held differing beliefs. In 2002, the Federal Constitutional Court reinstated the legality of halal slaughter, emphasizing that it was not the function of the court, but rather of the religious community itself, to decide what constituted proper religious practice. ${ }^{25}$ In the case of religious slaughter, however, the 2002 ruling did not end the matter. Following an al-Azhar University (Cairo) opinion that decreed that Muslims living in countries where they were not the majority were not required to practise halal slaughter, the Constitutional Court again ruled in 2005 that a Muslim butcher in Hessen could continue to practise religious slaughter. At issue was the non-universal acceptance of the Cairo ruling by Muslims and the question of whether the importation of halal meat would serve the needs of the Muslim community in Germany. ${ }^{26}$

German bans on ritual slaughter, however, are not new phenomena. In the 1890s, Saxony prohibited Jewish slaughter, arguing that stunning the animal before killing it was both less cruel and safer for the slaughterers themselves. Supporters of ritual slaughter — a group not limited to Jews — argued for both the religious freedom of German Jews and for the hygienic quality of bled-out meat, suggesting that it was less diseased than meat from animals killed using (Christian) slaughtering practices. ${ }^{27}$ During the Weimar era, Jews were permitted to practise ritual slaughter. In 1933, however, the Nazi government again forbade shechita slaughter and mandated stunning. Following the Holocaust, West German Jews regained the right to slaughter animals in a manner concordant with their religion. ${ }^{28}$

David Smith argues that the growing population of Muslims in West Germany in the 1970 s and 1980 s prompted renewed concerns about religious

\footnotetext{
25 David Smith, “'Cruelty of the Worst Kind': Religious Slaughter, Xenophobia, and the German Greens,” Central European History 40.1 (2007): 89, 112-113.

${ }^{26}$ Lerner and Rabello, 41-42. For a discussion of Sweden, where ritual slaughter is outlawed and the government subsidizes the cost of importing kosher and halal meat, see Tetty Havinga, "Regulating Halal and Kosher Foods: Different Arrangements Between State, Industry, and Religious Actors," Erasmus Law Review 3.4 (2010): 242-244.

${ }^{27}$ Hal Levine, "New Zealand's Ban on Kosher Slaughtering,” Ethnology 40.3 (2011): 211.

${ }^{28}$ Smith, “Cruelty," 91-92.
} 
slaughter, but this time, the opposition was directly mostly against Muslims rather than Jews. The European Convention for the Protection of Animals for Slaughter in 1979, in which Germany was represented, adopted the resolution that animals should be stunned prior to slaughter; an exception was made for religious slaughter. ${ }^{29}$ In 1986, led by members of the Green Party who advocated for animal rights, the German government mandated that slaughter involve stunning, although it made exceptions for some religious communities whose rules proscribed stunning. ${ }^{30}$ Importantly, however, in arguments that would echo the 1995 federal ban on halal slaughter, the majority of the German population did not view ritual slaughter as a religious requirement for Muslims. By 1990, the majority of the Green party had shifted away from outlawing ritual slaughter to focus instead on a "commitment to improved status and respect for those deemed to be foreigners in Germany, arguing that it was unfair to allow ritual slaughter for Jews, but to prohibit it for Muslims. ${ }^{31}$ The 1995, 2002, and 2005 rulings have been discussed above.

In North America, we are accustomed to think of animal rights and ecological activists as generally adopting left-wing politics. As Smith demonstrates, however, it would seem that in the German debate about religious slaughter, "potentially valid animal welfare concerns had been co-opted into attacks on nonGerman minorities. The language of intervention set up Germans as humane, while resident migrants, especially Turkish Muslims, could not love animals because they were not German and were not citizens." 32 We see this particularly in the continued concern for animal welfare after the left-wing Greens abandoned the issue and in the question of whether ritual slaughter is a religious requirement for Muslims. As Smith queries, reflecting on the view held by those opposed to halal slaughter, "If religious law did not expressly require the procedure, why should Germans and German law tolerate a foreign cultural practice? [emphasis original]." 33 Opponents of halal slaughter practices seem to have set up a dichotomy between traditional,

\footnotetext{
${ }^{29}$ Lerner and Rabello, "Prohibition," 12-13.

${ }^{30}$ Smith, "Cruelty," 94-96.

${ }^{31}$ Smith, "Cruelty," 108.

32 Smith, "Cruelty," 99-100.

${ }^{33}$ Smith, "Cruelty," 95.
} 
German religious practices (which would include kosher slaughter by Jews) and foreign ritual slaughter by Muslims, understood to be a cultural rather than a religious practice, and therefore, not protected by German laws regarding religious freedom.

Smith's arguments concerning these multi-step bans on religious slaughter raise the question of how the German government and courts differentiated between shechita and halal slaughter. After all, both prohibit stunning, and one is not more violent than the other. I have postulated that traditional German religious practices, as understood in the late twentieth century, would have included Jewish customs, including kosher slaughter. There are reasons for this proposal. It is significant that Jews lost the right to practise kosher slaughter under the Nazi government and regained it shortly after the Holocaust. This past is certainly not lost on German policy-makers. During the 1982 Bundestag's Committee for Food, Agriculture, and Forests meeting, Hans-Jürgen Weichert of the Association of German Animal Protection acknowledged, in the midst of his speech opposing ritual slaughter, that the question of kosher slaughter was more problematic than was halal slaughter, because religious slaughter by Jews was a question imbricated with politics and history in a way Muslim practices — brought to Germany primarily by foreign workers from Turkey in the late twentieth century-were not. ${ }^{34}$

Additionally, an education in Judaism is sponsored in the public-school system under the laws of German religious freedom; there, it joins Catholicism and traditional forms of German Protestantism as varieties of religious education that are optionally provided to the children of devout parents. Ewing demonstrates that Islam has not enjoyed the same educational support by the German state; it was only in 2000 that the Islamic Federation of Berlin was authorized to offer religious education to Muslim children in the public-school system. This followed a 1997 decision that forbade such education. ${ }^{35}$ The issues, again, concerned the lack of doctrinal unity in Islam and the religion's novelty in Germany. As Ewing writes, "Judaism has been recast as an important element of the German nation and has an

${ }^{34}$ Smith, "Cruelty," 103.

${ }^{35}$ Katharine Pratt Ewing, "Legislating Religious Freedom: Muslim Challenges to the Relationship between 'Church' and 'State' in Germany and France," Daedalus 129.4 (2000): 48. 
important place in church-state institutional arrangements. But echoes of German nationalism and of guilt over the Holocaust still resonate loudly in Germany today.” She continues to warn that "there is considerable fear-coming from Muslims and liberal Germans alike - that the Muslim has supplanted the Jew as the threatening Other within.” 36

Lerner and Rabello specifically highlight the idea of using concerns to challenge religious practices. Concerning the idea of banning ritual slaughter, without specific reference to Germany, they are worth quoting at length:

If we were to consider the question of ritual slaughter from a separationist perspective [that is, the separation of religion and state], the most logical conclusion we might draw is that separation would entail non-interference by the state into religious practices such as ritual slaughter. Moreover, when secularization affects only minorities within the society, particularly when those minorities have little chance of gaining political ascendancy, we must recognize that the religious slaughter ban does nothing by way of separating church and state, but rather has the sole effect of restricting the basic freedoms of the minorities. ${ }^{37}$

They go on to note that most western countries have adopted the "rule-andexception approach" - that is, the majority decides upon a regulation generally applicable to everyone who engages in a particular practice (here, religious slaughter) and then makes specific exceptions for minorities who wish to deviate from the pre-determined ideal practice, as long as the society's general principles are not seriously contravened. ${ }^{38}$ In their discussion of the specific ritual slaughter situation in Germany, the authors address the issue of animal rights activists, arguing that because Germany and other western countries have not instituted mandatory vegetarianism, the putative concern for animal rights by the government seems questionable. ${ }^{39}$ Further, they suggest that because Muslims greatly outnumber Jews in Germany, the perceived impact on animal suffering would be much greater in halal slaughter than in its Jewish counterpart. ${ }^{40}$ The question remains, however, of allowing one set of minority religious rights while prohibiting another.

\footnotetext{
${ }^{36}$ Ewing, "Legislating," 40.

${ }^{37}$ Lerner and Rabello, "Prohibition," 21.

${ }^{38}$ Lerner and Rabello, "Prohibition," 27.

${ }^{39}$ Lerner and Rabello, "Prohibition," 30.

40 Lerner and Rabello, "Prohibition," 37.
} 
As seen, the debates surrounding halal slaughter have frequently turned on whether it is a religious requirement for Muslims or instead a cultural practice. The scriptural injunctions in the Qur'an to practise a particular form of slaughter would clearly seem to indicate a religious requirement. Even apart from denying religious autonomy to Muslims, however, interpreting halal slaughter as a cultural practice is problematic and continues to endanger Muslim identity. In his discussion of the ritual slaughter ban in New Zealand, Levine turns to sealing and whaling concerns among the Inuit, explaining that even after Canada outlawed sealing in 1983, the exception that it allotted to the Inuit still encouraged animal rights activists to claim that the Inuit were practising a destructive commercial activity and were not truly following their traditions. He argues that "such challenges segue into cultural attacks that destabilize the target group and undermine it socially and culturally." ${ }^{41}$ The charge that halal slaughter is not a Muslim religious requirement, along with the unclear position that Islam occupies within the German legal system, would indicate that such a destabilization is a risk for Muslim communities in Germany.

This threat to German Muslims, however, is not limited to restrictions placed on ritual slaughter, but rather extends to the 2012 circumcision ban. Drawing on the debates surrounding halal slaughter in Germany, we can find four themes to help elucidate the anti-Muslim elements of the Cologne court's ruling and its representation in the German media.

First, the question of whether a particular ritual is required by Islam surfaces in both debates. We have seen that in the 1995 federal ruling, the German court judged that halal slaughter was not a religious requirement for Muslims and was therefore not protected by the constitutional guarantee of freedom religion. The absence in the Qur'an of any injunction to circumcise has also played a role in the media's discussion of the circumcision ban. ${ }^{42}$ An analysis in the center-left Süddeutsche Zeitung not only emphasizes that the Qur'an contains no commandment

\footnotetext{
${ }^{41}$ Levine, "New Zeeland's Ban,” 212.

${ }_{42}$ There are references in the hadith to circumcision. One of the most prominent is from Sahih Bukhari, vol. 7, book 72, hadith 779: "I heard the Prophet saying: 'Five practices are characteristics of the fitra: circumcision, shaving the public hair, cutting the moustaches short, clipping the nails, and depilating the hair of the armpits."
} 
to circumcise, but also draws an explicit contrast between Muslims and Jews, noting that the latter do prescribe circumcision in their scriptures. ${ }^{43}$ For von Drach, the author of the article, this distinction alone seems to explain why circumcision is not necessary for Muslims; the majority of the analysis is devoted to demonstrating that infant circumcision is not necessary for Judaism. He notes that adult circumcision occurs among converts to Judaism and emphasizes the matrilineal descent of Jewish religious identity. There follows a lengthy discussion of Israeli Jews who choose not to circumcise their male sons and examples of alternative ritual ceremonies, such as that conducted by Rabbi Elyse Wechterman, with which this article opened. Concerning Islam, von Drach simply, laconically states that "history shows that religions change, that rituals are modified." ${ }^{44}$ Von Drach is much more concerned with demonstrating how Judaism can forego circumcision. Islam, without a scriptural prescription to circumcise, can simply change.

The conservative daily Die Welt took a much more strident tone in its examination of the ban, referring to male circumcision as a "heinous archaic custom" and comparing male circumcision to female genital mutilation (Genitalverstümmelung). ${ }^{45}$ The author, Necla Kelek, also notes that no ayah in the Qur'an commands that boys be circumcised. There is a brief acknowledgment that the hadith contain references to circumcision, but Kelek also states that there is dispute among Islamic scholars as to whether circumcision is a requirement or a "mere recommendation" (bloße Empfehlung). ${ }^{46}$ Throughout, the article focuses on Islam with no mention of Judaism, leaving the impression that it is the Muslim ritual alone that is heinous, archaic, and mutilating.

Kelek's reference to dispute among Islamic scholars provides our second theme. As seen in the discussion of religious slaughter, the lack of a unifying voice among Islamic jurists is a topic in German debates about Muslim religious practices.

${ }^{43}$ Markus C. Schulte von Drach, “Ratio zwischen Recht und Religion,” Süddeutsche Zeitung, accessed March 26, 2015, http://www.sueddeutsche.de/wissen/streit-um-das-beschneidungsurteil-ratiozwischen-recht-und-religion-1.1411544.

${ }^{44}$ von Drach, "Ratio."

${ }_{45}$ Necla Kelek, "Die Beschneidung_ein unnützes Opfer für Allah,” Die Welt, accessed March 26, 2015, http://www.welt.de/debatte/kommentare/article107288230/Die-Beschneidung-einunnuetzes-Opfer-fuer-Allah.html.

${ }_{46}$ Kelek, "Die Beschneidung." 
The relevance of this doctrinal disunity would certainly appear in the understanding that Muslims are divided as to which hadith, including those that discuss ritual slaughter and circumcision, are acceptable. For example, after the 2002 reinstatement of halal slaughter by the Federal Constitutional Court, the court had to re-affirm the legality of ritual slaughter for Muslims in 2005, following an opinion from the Al-Azhar University in Cairo that was not universally accepted by Muslims. Ewing's analysis of the position of Islam in the German public-school system also demonstrates the importance of the question of a multivocal Islam.

The lack of an exact day on which Muslim boys have to be circumcised would also seem to contribute to this theme. As discussed above, Jewish boysbarring any medical risk - are to be circumcised when they are precisely eight days old. In Islam, the day of circumcision is much more flexible. The boy whose circumcision prompted the 2012 Cologne court ruling was four years old. Kelek notes that her nephew was nine when he was circumcised, using his pain to demonstrate what she perceives as the barbarity of circumcision. ${ }^{47}$ This doctrinal disunity regarding circumcision connects to the ritual's absence in Islamic scripture. If one is pre-disposed to view Islamic circumcision as a cultural rather than a religious rite, the variability of the date on which the ritual should occur would only add credence to that belief.

It should also be noted that, interestingly, neither Christianity nor Judaism is doctrinally unified. Christian education is optionally provided to German schoolchildren in both Catholicism and Lutheran Protestantism, despite substantial religious differences between Catholics and Protestants. Additionally, there are multiple, smaller Christian denominations that are both present and tolerated in Germany, although their doctrines are not taught in the school system. Similarly, Judaism, which also enjoys a state-sponsored presence in German schools, contains differing viewpoints. And yet, the doctrinal disunity of these traditional German religions does not come under question in the same way that Islam does. As noted, von Drach does refer to differing practices in Judaism concerning circumcision, but

${ }^{47}$ Kelek, "Die Beschneidung." 
he does so to demonstrate how Judaism - as a religion - can transform in ways that he views as constructive. Islam is simply told to change itself.

The third area in which an examination of the ritual slaughter debates can inform our understanding of the Cologne circumcision ban is in the differing treatment accorded to Jews and Muslims in German society. As discussed, a representative of the Association of German Animal Protection noted in 1982 that prohibiting shechita slaughter would have political and historical implications that the proscription of halal slaughter would not involve. Additionally, it does not seem as though kosher slaughter faced any serious threats after its re-institution following the Holocaust. Judaism, as seen in the teaching of religion in German schools, is viewed as an historical, traditional religion in Germany whereas Islam is perceived as a foreign importation.

It is perhaps significant that the initial criminal charges that led to the 2012 circumcision ban were leveled against a Muslim physician who had performed a circumcision in accordance with his interpretation of Islamic law. The legal ruling itself does not mention Judaism or Jewish circumcision customs but is instead quite clear that it is discussing Islam. It explicitly states that older male children can decide for themselves if they wish to undergo circumcision as a "visible sign of belonging to Islam." 48 There seems to be a lack of understanding here regarding the circumcision ritual in Islam. As in Judaism, the circumcised penis is more than a visible marker of community identity; it is instead the sign of a special relationship with the religion's deity. It is, of course, always difficult to argue from silence, as the court ruling does not mention Judaism. Nevertheless, it is possible that while the court understood the significance of circumcision for Jews, it interpreted-as we have seen other commentators do-Muslim male circumcision as a recommendation rather than a religious requirement. It is not a stretch to imagine that the court was operating from a Christian framework in which wearing a crucifix, for example, is a visible sign of belonging to Christianity, but is not a doctrinal requirement.

${ }^{48}$ Landgericht Köln. 
The speed with which the Bundestag acted to overturn the ban is perhaps also telling. Seven years elapsed between the 1995 ban on halal slaughter in Germany and its 2002 re-instatement by the Federal Constitutional Court. Certainly, it can take some time to work through appeals processes in a legal system, but it is noteworthy that the Bundestag did not intervene in the matter during those seven years. Less than six months passed, however, between the blanket ban on circumcision, which affected both Jews and Muslims, and the Bundestag's resolution to restore the practice, an action taken only four months after legal charges were brought against Rabbi Goldberg.

The fourth theme that a discussion of ritual slaughter helps elucidate is the role of secularism and putatively secular concerns in the debate surrounding the circumcision ban. In both prohibitions, I propose, concerns understood by the German legal system to be secular were deployed to frame Muslims as culturally foreign and to exclude them as a religious Other. Most obviously, concerns for animal welfare were "co-opted," to use Smith's term, to advance attacks on Muslims in Germany, portraying German/European/Western slaughter practices as humane and halal slaughter as cruel. Importantly, the 1890 Saxon ban on kosher slaughter reminds us that secular concerns are neither fixed nor stable: some advocates of religious slaughter argued that the practice made meat more hygienic and less diseased. Here, the concern was for the cleanliness of food, not for animal welfare.

Regarding the circumcision ban, the court's decision turned on an interpretation of Article 6, Paragraph 2, Page 1 GG, in the German Basic Code, which deals with parental rights. The Cologne court advanced a narrow reading of the statute, understanding it to mean that parents are essentially caretakers and their decision rights only extend to minimizing harm to their children. ${ }^{49}$ Thus, the court's judgment indicated that while parents can provide their offspring with a religious upbringing, they are not allowed to alter their children's bodies as a means of advancing that education in religion. According to the court, male children could wait until they were older and make their own decisions regarding circumcision. This raises the question, however, of deciding at what age children are legally and

${ }^{49}$ Krüper, “Entscheidungsanmerkung,“ 549. 
cognitively capable of making decisions regarding their bodies. The Jewish injunction to circumcise male newborns when they are eight days old, of course, precludes any conscious decision on the part of the child, but it is unclear whether a thirteen-year-old Muslim boy would be able to fully understand the implications of having himself circumcised. Thus, even delaying circumcision until the child is older does not provide a clear solution.

In the initial case, however, during which the district court dismissed all charges against the physician who had performed the circumcision, the court's decision was partially influenced by the idea that circumcision could have hygienic motivations. As we have seen, although circumcision may convey medical benefits, the issue is still debated by physicians. The analyses in the Süddeutsche Zeitung and Die Welt both discuss the uncertain medical benefits of circumcision and emphasize its potential harms, such as a reduction in sexual pleasure. ${ }^{50}$ As noted, the American Academy of Pediatrics in the United States, where circumcision is most frequently practised for non-religious reasons, has cautiously advocated for routine male circumcision, but its position on the issue has not been consistent in recent decades.

More important for our understanding of the circumcision ban, however, is the district court's use of a secular, medical rationale to provide a ruling on circumcision practised for religious reasons. According to Krüper, the court did acknowledge that circumcision would allow the four-year-old boy to avoid stigmatization in his religio-cultural environment, but the inclusion of a medical reason for the ritual seems to indicate that the court needed additional justification for its decision. The ritual reasons of a foreign, imported religion did not suffice. Rather, instead of relying on a Muslim understanding of Islamic religious prescriptions, the court instead turned to the more universal (and not wholly religious) idea of group identity and to the secular, western understanding of circumcision as a medical procedure undertaken for specific, potentially hygienic reasons.

\footnotetext{
50 See von Drach and Nekel.
} 
The 2012 circumcision ban in Cologne, Germany sparked a national debate about religious freedom and the ethics of ritual practices. Although the ban affected both Jews and Muslims, I argue that it targeted-perhaps unconsciously-only the latter group. An examination of Germany's complicated history with halal slaughtering practices has demonstrated that the German legal system has been previously, and recently, used to circumscribe Islam while allowing an analogous practice by Jews. In addition to the use of doctrinal (dis)unity among Muslims and the question of whether it is a religious requirement or recommendation, the practice of circumcision has been debated using secular concerns, including bodily integrity, parental rights, and medical benefits—none of which are solely religious issues or evince an understanding of Islam. Rather, the ban and the topics used to debate it would seem to indicate an exclusion of Muslims from German society, as was, arguably, previously attempted during the halal slaughter prohibitions.

Additionally, as we have seen with the need for yet another ruling about Muslim slaughtering practices, in 2005 , the discriminatory proscriptions can resurface, even after they have ostensibly been settled at the federal level. This leaves open the possibility that the German circumcision ban may not yet be settled. 


\section{Bibliography}

Alanis, Mark C. and Richard S. Lucidi. "Neonatal Circumcision: A Review of the World's Oldest and Most Controversial Operation," Obstetrical and Gynecological Survey 59.5 (2004): 379-395.

American Academy of Pediatrics. "Circumcision Policy Statement," Pediatrics 130.3 (2012): 585-586.

Anidjar, Gil. "Secularism," Critical Inquiry 33.1 (2006): 52-77.

Asad, Talal. Formations of the Secular: Christianity, Islam, Modernity. Stanford: Stanford University Press, 2003.

Benatar, Michael and David Benatar. "3:2 Target Article Authors respond to Commentators: How Not to Argue about Circumcision,” The American Journal of Bioethics 3.2 (2003): 1-9.

---. "Between Prophylaxis and Child Abuse: The Ethics of Neonatal Male Circumcision," The American Journal of Bioethics 3.2 (2003): 35-48.

Cruz, Rio, Leonard B. Glick, and John W. Travis. "Circumcision as Human-Rights Violation: Assessing Benatar and Benatar," The American Journal of Bioethics 3.2 (2003): 19-20.

Ewing, Katharine Pratt. "Legislating Religious Freedom: Muslim Challenges to the Relationship between 'Church' and 'State' in Germany and France," Daedalus 129.4 (2000): 31-54.

Evans, Stephen. “German Ccircumcision ban: Is it a parent's right to choose?” $B B C$. Accessed March 22, 2015. http://www.bbc.com/news/magazine-18793842.

Glick, Leonard B. Marked in Your Flesh: Circumcision from Ancient Judea to Modern America. New York: Oxford University Press, 2005.

Hans, Barbara. "Landgericht Köln: Beschneidung aus religiösen Gründen ist strafbar.” Spiegel Online. Accessed March 23, 2015. http://www.spiegel.de/panorama/justiz/religioes-motivierte-beschneidungvon-jungen-ist-laut-gericht-strafbar-a-841084.html.

Havinga, Tetty. "Regulating Halal and Kosher Foods: Different Arrangements Between State, Industry, and Religious Actors," Erasmus Law Review 3.4 (2010): 241-255.

Kelek, Necla. “Die Beschneidung_ein unnützes Opfer für Allah,” Die Welt. Accessed March 26, 2015. http://www.welt.de/debatte/kommentare/article107288230/DieBeschneidung-ein-unnuetzes-Opfer-fuer-Allah.html.

Krüper Julian. "Entscheidungsanmerkung. Religionstradition und Rechtskonvention: Die Unzulässigkeit religiöser Knabenbeschneidung,” Zeitschift für das Juristische Studium 4 (2012): 547-552.

Landgericht Köln. Urteil 151 NS 169/11. IWW Institut. Accessed March 30, 2015. http://www.iww.de/quellenmaterial/id/85915.

Lerman, Steven E. and Joseph C. Laio. "Neonatal Circumcision,” Pediatric Clinics of North America 48.6 (2001): 1539-1557.

Lerner, Pablo and Alfredo Mordechai Rabello. "The Prohibition of Ritual Slaughtering (Kosher Shechita and Halal) and Freedom of Religion of Minorities," Journal of Law and Religion 22.1 (2006/2007): 1-62.

Levine, Hal. "New Zealand's Ban on Kosher Slaughtering," Ethnology 40.3 (2011): 209-222. 
Robbers, Gerhard. "The Legal Status of Islam in Germany.” In Islam and European Legal Systems, edited by Silvio Ferrari and Anthony Bradney, 147-154. Burlington, VT: Ashgate, 2000.

Roberts, Christine. The unkindest cut of all: German rabbi faces charges for performing newly outlawed circumcision procedure.” New York Daily News. Accessed March 24, 2015. http://www.nydailynews.com/lifestyle/health/unkindest-cut-german-rabbi-faces-charges-performing-newlyoutlawed-circumcision-procedure-article-1.1142324.

Rubin, Nissan. "Brit Milah: A Study of Change in Custom." In The Covenant of Circumcision, edited by Elizabeth Wyner Mark, 87-97. Hanover and London: Brandeis University Press, 2003.

Scholz, Kay-Alexander. "Circumcision remains legal in Germany." Deutsche Welle. Accessed March 23, 2015. http://dw.de/p/16oDQ.

Smith, David. "Cruelty of the Worst Kind': Religious Slaughter, Xenophobia, and the German Greens," Central European History 40.1 (2007): 89-1 15.

von Drach, Markus C. Schulte. "Ratio zwischen Recht und Religion," Süddeutsche Zeitung. Accessed March 25, 2015.

http://www.sueddeutsche.de/wissen/streit-um-das-beschneidungsurteilratio-zwischen-recht-und-religion-1.1411544.

Wechterman, Elyse. “A Plea for Inclusion.” In The Covenant of Circumcision, edited by Elizabeth Wyner Mark, 188-193. Hanover and London: Brandeis University Press, 2003. 